\title{
The Deconstruction of Oppressive Structures: Three Non-Conforming Female Figures in Canadian Drama
}

Sophia Charyna*

\begin{abstract}
Sometimes, resistance to oppressive structures takes on forms initially unexpected. Through close readings of George Ryga's The Ecstacy of Rita Joe, Judith Thompson's The Lion in the Street, and David French's Salt-Water Moon, this paper considers four female figures in Canadian drama who oppose their circumstances leveraging the-sometimes minimalpower available to them.
\end{abstract}

Keywords: Canadian drama, George Ryga, close reading, Canadian literature

George Ryga's The Ecstasy of Rita Joe, Judith Thompson's Lion in the Streets and David French's SaltWater Moon are examples of Canadian plays that feature female characters placed in challenging situations: poverty, illness, death, and in the case of Salt-Water Moon, a difficult and life-changing decision. Each woman-Rita Joe, Joanne, Isobel, and Mary-is faced with institutional and personal challenges and oppose them by rebelling against patriarchal norms. By opposing the systems that oppress or challenge their sovereignty, these female figures do not abide by the status quo and thus deconstruct the very systems that aim to assimilate them.

Given the painful inspiration of The Ecstasy of Rita Joe-a news article of a female corpse found in downtown Vancouver, Ryga's approach to Rita's character is sympathetic and careful. Moments within the courtroom episodes reveal how, despite the hardships in her life, Rita continues to oppose the colonial, patriarchal and racist legal structures that oppress her. However, while expressing the horrors of this life he has imagined, Ryga continues to characterize Rita Joe as a vocal woman who does not back down from the challenges put in her path. Even once she has been sentenced and spent time in jail, she continues to tell the Magistrate just what she thinks of his so-called power: nothing. In "Staging the Human in George Ryga's The Ecstasy of Rita Joe," Saradindu Bhattacharya discusses the colonial powers at work that aim to reduce Rita's "individual subjectivity to a set of colonial stereotypes" (47). In each appearance in the courtroom, the Magistrate continues to cast her in the role of the criminal, without pause to hear her speak, even though he states that because she knows English, she should speak:

Because Rita is already identified only in
stereotypical racial terms, the
establishment of the charges levelled
against her becomes merely a predictable
formality rather than an exercise in fair and
objective judicial scrutiny of evidence.
Thus, the Magistrate ignores Rita's

Because Rita is already identified only in stereotypical racial terms, the establishment of the charges levelled against her becomes merely a predictable formality rather than an exercise in fair and Thus, the Magistrate ignores Rita's

\footnotetext{
* Department of English, College of Arts and Science, University of Saskatchewan, Saskatoon, SK, Canada
} Correspondence: sophia.charyna@queensu.ca 
statement that she was framed falsely on the charge of prostitution. (39)

With each appearance in front of the Magistrate, as Rita begins to lose strength and hope in the system, she continues to maintain a fire of opposition to the structures that have trapped her: colonialism, racism, patriarchy, and poverty.

When Rita appears in front of the court to defend herself from the prostitution charge, she tries to explain her side of the complex interaction. She is not listened to, and the murderers grow closer as the Magistrate yells: "Answer me! Drunkenness! Shoplifting! Assault! Prostitution, prostitution, prostitution, prostitution!" (Ryga 77). The approach and the physical threat of the murders add to the already cacophonous and chaotic nature of the scene. The murderers get closer than ever before and are a more active threat, and Rita receives her worst sentence, even when she is innocent. Despite all of these threats, Rita refuses to 'buyin' to the shame that the court continually thrusts upon her: "You got rules here that was made before I was born... I was hungry when I stole something ... an' I was hollerin' I was so lonely when I started whoring" (77). Each time that she represents or defends herself, she is effectively reversing the gaze of the court back onto the court itself: she "reverse[s] the focus of interrogation, thus 'trying' the system which creates criminals from the remains of its own victims" (Boire 9). Rita does not relent before the colonial powers of the legal system that holds her. The government has failed her people and has failed her. The courtroom scenes when Rita engages with the systems to reveal their weaknesses evidence an active refusal to comply with colonial demand. In these same moments, Ryga is pointing a finger to the audience, implicating them to leverage these weaknesses into substantial change. In her final moments, Rita does not let her rape be what ultimately ends her life. It is almost as if she regains control of her life path and knows that it is better to die in that moment than to wait a minute more; while a horrible prospect, this act grants her the satisfaction of sovereignty over her own body, and, further, her life. In a life of opposition and resistance this final moment culminates Rita's battle against forces of racism and patriarchy; and this time, she wins.

Joanne and Isobel in Lion in the Street are examples of female characters who refuse to conform to normative conventions of death: Joanne does so by her insistence in manufacturing the moment, images, and memories of her death, and Isobel, by her remaining existence on earth after death. Evidently, Joanne wants autonomy over her death but also her bodily image in death and her memory. As soon as she begins to anticipate that she is going to die, Joanne asks Rhonda to be an accomplice in her final performance: replicating Millais' rendition of Ophelia in the water from her childhood memory: "I want you to help me, with the flowers, with the branches, and my hair" (271). Perhaps, for Joanne, the action of taking control of her life and death will allow her a peaceful transition between the two, unlike young Isobel who met the end of life through violence. She explains her beliefs about the painted Ophelia: "she dies... good. She dies good," "I want to die like that" (271). Rhonda sympathizes with her dear friend's grief and anxiety over her terminal illness; yet, she discredits any validity to what Joanne has said. Richard Paul Knowles articulates the reluctance and realism that Rhonda expresses, quoting: "Jo you're talkin cigarette packages and used condoms and old tampons floating by you're talking freezin" "You can't become a picture, do you know what I mean? I mean you can't... BE... a picture, okay?" (271-2). In Joanne's case, the need to create a beautiful 'image' of death is influenced by patriarchal pressures of beauty and acceptability. Perhaps, by voicing to her dear friend these fears and dreams of death, Joanne gives Rhonda an opportunity to speak against patriarchy to give Joanne a more nuanced perspective, to push back against internalized expectations and worries. Ultimately, the scene is interrupted before the audience knows how Joanne's life ends. What is noteworthy, though, is her willingness to not only speak openly about her illness and death. She does not succumb to the potential shame that could be pushed upon her to stay quiet about 'delicate' subjects. This loving negotiation between friends, represented by Thompson amongst other discordant 'episodes' of her play, contrasts the story of Isobel who rejects death altogether to remain on earth as a ghost. She does not pass on gently or beautifully or peacefully as Joanne may wish to.

Isobel remains in the world for 17 years after her murder warn others of the danger around them as well as confront the man who ended her young life. Claudia Barnett discusses how Isobel uses her position as an opportunity to gain power as she "eventually understands that, as a ghost, she has a certain kind of power. While outside forces have made her what she is, she also has an inner force" (114). Isobel's reversal of the assumed passage of death is subversive: the murdered girl remains and warns others; further, she knows that her death was wrongful and demands for her life back. She should have never died at nine years old and is sure to tell this to Ben: "I want my life back! Give me back my life!" (Thompson 287). In the episode's final moments, when Isobel confronts Ben she is prepared to attack him-the stage directions read: "She is about to kill him with the stick" (288). Her final decision to say that she loves him instead of landing a lethal blow subverts the way in which she has opposed death. Barnett's concept of inner power is not used for retributive nor violent means, instead she uses her inner strength to find closure and peace. Once Isobel realizes that killing Ben or manufacturing the 'revenge' she thought she needed, will never result in a return to life as she may have hoped, she rests. She 
recognized the incompatibility with her child self and the world she has lingered in. By recognizing that her only path to peace is through forgiveness, not the return of violence onto another body, Barnett notes, "she may be dead, but she has come to terms with, and in fact created, a viable identity, and as a result, she ascends heaven" (Barnett 114). Isobel puts down her weapon, lets herself age beyond childhood, appearing as an adolescent, then adult, she begins to transition-not because it is the convention of death that she must follow-but because she is at peace and ready to go. Once donning her veil, she lifts into the afterlife, leaving behind one last message: "I take my life, I want you all to take your life, I want you all to have your life" (288). This final image is powerful not only in catharsis for the audience, but the knowledge that in her final moments, Isobel has the agency to make the decision not to kill her murderer, and claims her power to exclaim instead: "I love you" (287).

Facing a challenging question, Salt-Water Moon's Mary Snow must choose between her fiancé and returned old flame, Jacob. The decision navigates the ramifications of such a commitment: potential financial and social consequences of ending her engagement and beginning another one and cultural opinions deriving from a decision such as this in her family and the local community. However, Mary's final choice to break off her engagement to Jerome is subversive in that she chooses to disregard the social expectation of marriage to someone 'safe' or 'reliable.' By ending her engagement, she is taking herself out of an expectedly dependable position. By marrying Jerome, she would be able to protect and provide for her sister. He has a steady income, and a home and Mary hates the idea of hurting him: "What did you expect l'd do boy? Cancel the wedding next month? Hurt someone the way that you hurt me? Did you imagine I was pining away that much?...All you have to do is walk across the Klondike into Coley's point, and I'm expected to feel the same? Expected to feel grateful?" (French 58). Despite Mary's conflict, the play focuses primarily on Jacob's feelings towards Mary, and the question of her reciprocity.

Richard Plant's review of the play focuses on French's psychological storytelling that "gives us a full view of the inner forces driving Jacob and Mary's actions and of the Newfoundland society that has shaped their inner selves" (Plant 16). This psychological perspective is expanded on in Robert Nunn's "The Subjects of Salt Water Moon." Nunn's approach produces close readings of various relevant passages and examines how the male gaze is pandered to or opposed, depending on the subjectivity of the reader. In the circumstance of a live performance the actor and actress and audience members are each considered individually: "The actor's subjectivity thus can add a perspective that interrupts and contests an orthodox reading of the play, and can perhaps in Brechtian fashion produce a divided audience, one in which a woman and a man seated next to each other may have sharply different responses" (15). The reading congruent with this argument, Mary's choice of Jacob is a non-conforming act and actively reject the social structures that may have limited her agency in this choice, but be centered on the fact that the reader is a young woman. Each reader's positionality will determine, to some degree, how they understand the power balance between Mary and Jacob as well as the weight of Mary's choice in her historical context. Likely, this decision would not be looked upon well by the community, and yet it is the choice that Mary makes.

While she carries the adult burden of looking out for her sister Dot, Mary is still a teen. On one August night with Jacob she abandons adult ideas of reliability and safety, ideas that she has been persuaded are more important than her own happiness. Instead, she chooses to build a life with Jacob and Dot rather than live in the life that Jerome and societal expectations have built for her. This final decision comes from a deep place in Mary's psyche that has considered her happiness and wellbeing as well as her sister's. She does not make this decision purely because she has been wooed and won in a single night. Like Isobel in Lion in the Street, Mary considers what she truly wants and how she can achieve those goals. She decides for herself, just as Isobel decides not to kill Ben, to take the risk of a future with Jacob. By deciding to break with convention and what could be called 'common-sense,' Mary may make herself a target within her community; however, this decision is also a statement. It is a message to other young women that they have the right to change their minds and the power to do what they know is best for them. This message will fluctuate and change through the decades, but it is a starting point to a greater reckoning of women's agency.

In The Ecstasy of Rita Joe, Lion in the Street, and SaltWater Moon, Ryga, Thompson, and French are writing female characters who refuse to be victims within their circumstances. They choose to make decisions not based on the opinions of society but their own minds. Rita's rejection of shame amidst struggle is a powerful statement that has and will continue to implicate audiences in her demise as well as push them toward changing the broken systems that killed her. Isobel and Joanne represent their experiences authentically and offer a perspective on death that is not often spoken. Finally, Mary's decision to listen to her own voice of reason to make the best decision for herself and her sister despite any resistance or opposition she will face as a result is a small example of a single women's impact to challenge patriarchy, and lead others to follow. The women in these works rise to each challenge and encourage their audiences to do the same. 


\section{Works Cited}

Barnett, Claudia. "Judith Thompson's Ghosts." Canadian Theatre Research. Issue 114, 2003, pp. 33-37.

Bhattacharya, Saradindu. "Staging the Human in George Ryga's The Ecstasy of Rita Joe." Rupkatha. Vol. 11, No. 1, 2019, pp. 37-45.

Boire, Gary. "Tribunalations: George Ryga's Postcolonial Trial 'Play."' ARIEL. Vol. 22, No.2, 1991, pp. 5-20.

French, David. Salt-Water Moon. Talonbooks, 2017.

Harvie, Jennifer. "Constructing Fictions of an Essential Reality or 'This Picksur Is Niiiice': Judith Thompson's Lion in the Streets". Theatre Research in Canada / Recherches théâtrales Au Canada, Vol. 13, No. 1, 1992.

Knowles, Richard Paul. "'The Real of It Would Be Awful': Representing The Real Ophelia in Canada." Theatre Survey. Vol. 39, No. 1, 1988, pp. 21-39.

Nunn, Robert. "The Subjects of Salt Water Moon." ENG 358.3 (Wo1) Course Materials: Readings PDF and Online. Blackboard Learning Material. Accessed 19 Nov. 2019.

Plant, Richard. "The Plots Thicken." Books in Canada. Vol. 15, Iss. 3, 1986, pp. 16.

Ryga, George. The Ecstasy of Rita Joe. Talonbooks, 1970.

Thompson, Judith. Lion in the Streets. ENG 358.3 (Wo1) Course Materials: Readings PDF and Online. Blackboard Learning Material. Accessed 19 Nov. 2019. 